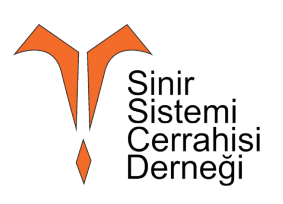

\title{
Effectiveness and success rates of endoscopic third ventriculostomy in patients under 2 years old
}

\section{Endoskopik üçüncü ventrikülostominin 2 yaş altı hastalarda etkinliği ve başarı oranları}

\author{
Murat Ertaş $^{1 \oplus}$, Derya Karaoğlu Gündoğdu ${ }^{1 \oplus}$, Mert Şahinoğlu $^{1 \oplus}$, Ender Köktekir ${ }^{1 \oplus}$, \\ Hakan Karabağlı ${ }^{1 \odot}$
}

'Selçuk Üniversitesi Tıp Fakültesi Beyin ve Sinir Cerrahisi, Konya.

Atıf/Cite as: Ertaş M, Karaoğlu Gündoğdu D, Şahinoğlu M, Köktekir E, Karabağlı H. Effectiveness and success rates of endoscopic third ventriculostomy in patients under 2 years old. J Nervous Sys Surgery 2021;7(2):67-71.

Geliş tarihi/Received: 07.05.2021 Kabul tarihi/Accepted: 18.05.2021 Yayın tarihi/Publication date: 30.10.2021

\begin{abstract}
Objective: Endoscopic third ventriculostomy (ETV) stands out as an important option in the treatment of hydrocephalus without shunts. Endoscopic third ventriculostomy (ETV) has become more popular due to recent technical developments in endoscopic systems. But the urge of the physician, to provide a shuntfree survival for his patients, leads to performing the procedure in a unsuitable group of patients. Compared with shunt surgery, ETV presents a more physiological solution for the treatment of hydrocephalus. ETV is accepted as the first-line treatment method in many centers in appropriate cases in the treatment of obstructive hydrocephalus. The aim of this study is to examine the results of patients under the age of two underwent endoscopic third ventriculostomy. Methods: 79 patients who underwent ETV between 2011 and 2020 in our clinic and who were under 2 years of age at the time of operation were retrospectively analyzed.

Results: 45 of 79 patients were male babies and 34 were female babies. The average age of the patients is 7 months (1 day - 22 months). In 39 (49.3\%) patients, there was no need for repeat surgery in their follow-up after ETV. ETV procedure was repeated in $5(6.3 \%)$ patients, and ventriluloperitoneal shunt (VPS) surgery was performed in $2(2.5 \%)$ patients. In 13 patients, ventriculoperitoneal shunt was applied from the anterior and presented with shunt dysfunction. VPS surgery was not performed again after ETV in $3(23 \%)$ of 13 patients after ETV.

Conclusions: ETV can also be applied to patients younger than two years of age, and this treatment can give patients the chance to live a life independent of shunt.
\end{abstract}

Keywords: Endoscopic third ventriculostomy, Hydrocephalus, Outcomes of ETV

ÖZ

Amaç: Endoskopik üçüncü ventrikülostomi (ETV) hidrosefalinin şantsız tedavisinde önemli bir seçenek olarak ön plana çıkmaktadır. Günümüzde ilerleyen teknoloji endoskopik üçüncü ventrikülostomiyi (ETV) daha popüler hale getirmiştir. Hekimlerin hastalarına şanttan bağımsız bir hayat sunabilme arzusu, bu tekniğin ideal sayılamayacak hasta gruplarında da uygulanmaya başlamasını sağlamıştır. Şant cerrahisi ile kıyaslandığında, ETV hidrosefali tedavisi için daha fizyolojik bir çözüm sunmaktadır. ETV obstrüktif hidrosefalinin tedavisinde

\footnotetext{
Sorumlu yazar/Corresponding author: Murat Ertaş, Selçuk Üniversitesi Tıp Fakültesi Beyin ve Sinir Cerrahisi, Konya. civsurgeon@yahoo.com / 0000-0001-5722-9832

ORCID:

D. Karaoğlu Gündoğdu 0000-0003-2345-8818, M. Şahinoğlu 0000-0003-0633-8304, E. Köktekir 0000-0002-6442-6663, H. Karabağlı 0000-0002-1184-3965
}

(C) Telif hakkı Sinir Sistemi Cerrahisi Dergisi

Bu dergide yayınlanan bütün makaleler Creative Commons 4.0 Uluslararası Lisansı (CC-BY) ile lisanslanmıştır.

(c) Copyright Journal of Nervous System Surgery.

Licenced by Creative Commons Attribution 4.0 International (CC BY). 
uygun olgularda birçok merkezde ilk seçenek tedavi yöntemi olarak kabul edilmektedir. Bu çalışmada amaç, endoskopik third ventrikülostomi uygulanan iki yaşından hastaların sonuçlarını incelemektir.

Yöntem: Kliniğimizde 2011 - 2020 yılları arasında ETV uygulanmış ve uygulama esnasında 2 yaş altında olan 79 hastayı retrospektif olarak incelendi.

Bulgular: 79 hastanın 45' i erkek bebek, 34' ü kız bebektir. Hastaların ortalama yaşları 7 aydır (1 gün - 22 ay). 39 (\% 49.3) hastaya ETV sonrası takiplerinde tekrar cerrahi müdahaleye gerek olmamıştır. 5 (\% 6,3)hastaya ETV prosedürü tekrarlanmış 2 (\% 2,5)' ine ventrilüloperitoneal şant (VPS) cerrahisi uygulanmıştır. 13 hastada öbceden ventriküloperitoneal şant uygulanmış olup şant disfonksiyonu sebebi ile başvurmuştur. ETV sonrası 13 hastanın 3 (\% 23)' ünde ETV den sonra yeniden VPS cerrahisi uygulanmamıştır

Sonuç: ETV, iki yaşından küçük hastalara da uygulanabilir ve bu tedavi hastalara şanttan bağımsız bir hayat sürme şansını tanıyabilir.

Anahtar Kelimeler: Endoskopik ücüncü ventrikülostomi, Hidrosefali, ETV sonuçları

\section{INTRODUCTION}

Nowadays, endoscopic third ventriculostomy (ETV) is accepted as the first treatment option in obstructive hydrocephalus ${ }^{(6)}$. ETV procedure is not a surgery limited by definite indications. Surgeons dealing with pediatric neurosurgery who seeks shunt freee treatment for hydrocephalus, especially for newborns and young children, felt the need to expand their ETV indications (14). Since the 1950s, ventriculoperitoneal shunt (VPS) application has been accepted as an effective treatment of hydrocephalus. this long process also means many years for surgeons to deal with VPS complications. The main reason behind the ETV procedure is provide shunt free life for patients. Until recently, it was stated that endoscopic third ventriculostomy should not be performed in patients under the age of 1 due to arachnoid granulation immaturation ${ }^{(10)}$. On the other hand, although success rates are low in patients under 2 years of age, there are also studies that argue that endoscopy can be used routinely in all appropriate situations ${ }^{(3)}$. In these studies, ventriculoperitoneal shunt therapy is recommended if ETV is not efficient or its effectiveness decreases over time ${ }^{(3,18)}$. The aim of this study is to evaluate the results of ETV applied in our clinic under 2 years of age.

\section{MATERIAL AND METHOD}

Patients under 2 years of age who underwent ETV procedure between March 2010 and March 2021 in the Department of Neurosurgery of
Selcuk University Faculty of Medicine were evaluated retrospectively. Among the patients who underwent ETV, 79 patients who were 2 years old and younger during the operation and who had complete control examinations were included in the study. Among the patients who underwent ETV, 79 patients who were 2 years old and younger at the time of the operation and regularly attended the control examination were included in the study. While the patients were included in the study, previous hydrocephalus surgery was not one of the exclusion criteria. The patients' age, gender, underlying diagnoses, how long they benefited from the first surgery, whether the second endoscopic third ventriculostomy was performed, whether there was a need for a ventriculoperitoneal shunt after the first operation, and how long it was after ventriculoperitoneal shunt surgery were evaluated. In the follow-up of patients after endoscopic third ventriculostomy, all cases that did not require shunt were considered successful (Figure 1).

\section{RESULTS}

Of the 79 patients included in the study, 45 (\%56, 9) were male babies and $34(\% 43,1)$ were female babies. The age of the patients during ETV operation ranges from 1 day to 22 months, with an average of 7 months. Cerebrospinal fluid (CSF) flow was observed by opening a hole in the Tuber Cinerium in all 79 procedures. Mean follow-up time was 59, 5 months (24 days - 132 months). No operation was required for hydrocephalus after ETV in 39 (49.3\%) of 79 patients (Figure 

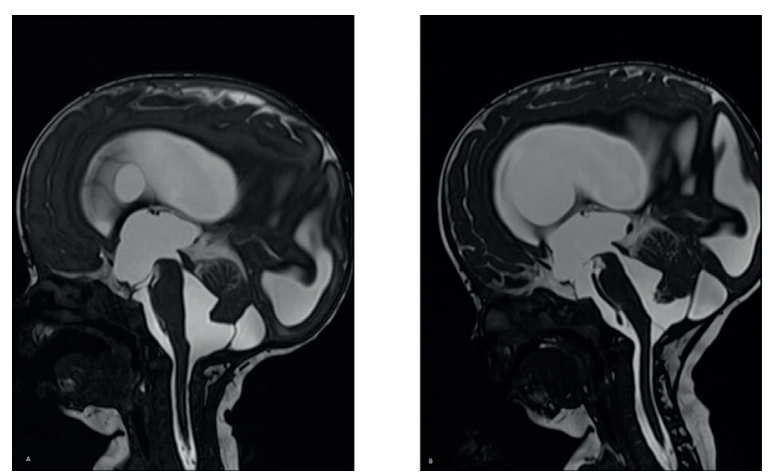

Figure 1A - Patient with aquaductus stenosis before ETV 1B - CSF circulation seems to improve after ETV

2). $40(50 \%)$ patients who did not fully benefit from ETV treatment underwent re-surgery. ETV was re-applied in $5(6,3 \%)$ patients after an average of 84 months (48-130 months) after the first ETV procedure. $3(60 \%)$ of them did not need another surgery. VPS was placed in other 35 patients, but $11(27,5 \%)$ of them required more than one operation due to complications and VPS dysfunction. The average time between VPS placement after ETV was 3 months (1 day to 55 months).

ETV was applied as the first procedure in 66 $(\% 83,5)$ patients without previous treatment for hydrocephalus. $13(16,3 \%)$ patients had a history of ventriculoperitoneal shunt (VPS) operation before ETV. All of these 13 (16, 3\%) patients who underwent VPS excision due to shunt dysfunction were applied ETV first, and no other surgical treatment was required for $3(23 \%)$ of them. VPS placement operation was renewed for the other 10 patients.
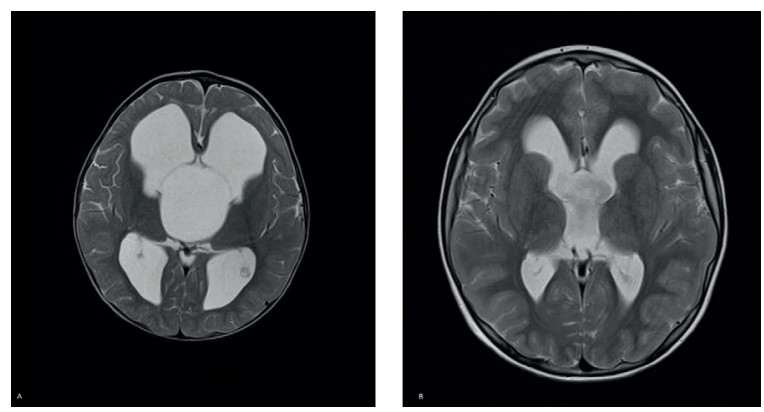

Figure 2A - Triventricular hydrocephalus before ETV 2B - Appearance of the ventricles after 9 years of follow-up
In our clinic, there is a history of revision due to shunt dysfunction in the follow-up of 11 patients who underwent VPS implantation after ETV. Shunt dysfunction in these patients was attributed to infection in 5, abdominal complications (ileus etc.) in 4 patients, and dislocation of the abdominal tip of VPS in 2 patients.

\section{DISCUSSION}

Despite the shunt technology that develops with technological improvement, shunt systems cannot fully satisfy the expectations. Considering the shunt complications, especially in the pediatric age group, alternative treatment systems have come to the fore. $33 \%$ of patients with shunts suffer from shunt dysfunction in one year, 50\% in 2 years and $70 \%$ within 10 years ${ }^{(1)}$. In the literature, a 31-year-old patient who underwent 56 shunt revisions was presented as a case report (8). Shunt dysfunction is the terrifying of both the surgeon and the patient. Although VPS placement is not a difficult procedure, the patients suffering from shunt dysfunction and being exposed to frequent hospitalizations and revision surgeries are actually a socio-cultural problem. It is the desire of every surgeon to give a shunt free life chance for patients with hydrocephalus. In this respect, the fact that $39(49,3 \%)$ of 79 patients who underwent ETV had not performed any other surgery for hydrocephalus means that ETV is an option for us to be offered to these age groups. In the literature, it is mentioned that patient age is an important factor affecting the success of ETV and a low success rate in the younger age group ${ }^{(4)}$. In studies evaluating the success of ETV in the pediatric age group, the lowest success rate was reported to be $23 \%$ and the highest success rate between $83-89 \%{ }^{(4)}$. However, children under 2 years of age were not mentioned in any of these studies. In this regard, our success rate of $49.3 \%$ belongs to a more specific age group. 
The most suitable patient population for ETV is those with obstructive hydrocephalus, large third ventricle, open subarachnoid space and no impaired CSF absorption. In line with this information, the most suitable patient group is patients with aquaduct stenosis. It is known that both the cause of obstruction and CSF absorption are sufficient in these patients. Success rates varying between 50-91\% have been reported in patient groups which suitable with these criteria $(4,8,14)$. The reason for the difference in ETV success rates in the literature is its application in non-ideal patients and the lack of a technique to measure CSF absorption capacity ${ }^{(14,15)}$. The same handicaps were mentioned in our study. ETV was applied as the first option in every symptomatic hydrocephalus patient for whom ETV application is not contraindicated. In our study, the fact that 13 patients had previously applied VPS and applied with VPS dysfunction thought that CSF absorption may not be sufficient in these patients. However, the lack of a radiological examination to prove this has encouraged us to apply ETV primarily in these patients. These patients were followed very closely. VPS placement operation was performed on one of them the next day. 9 of them had an operation of placement VPS within an average of 3 ( 1 day to 55 months) months. However, no operation was required for 3 (23\%) of them in terms of hydrocephalus. Even this group, which we know is not very suitable for ETV, has a success rate of $23 \%$, which made us consider that ETV procedure is worth to try. It should be tried as the first treatment option in obstructive hydrocephalus including ETV aquaduct stenosis ${ }^{(4,12)}$.

Until recently, it was thought that ETV should not be applied in patients under two years of age, since arachnoid granulations are not fully developed (10). In the literature, when the success rate of patients under the age of two is compared with the success rates of patients over the age of two, the results were found to be significantly lower $(11,16)$. For the group who are suitable for ETV but under 2 years of age, it was recommended to place a shunt first to reduce intracranial pressure and to give chance for the development of arachnoid granulations, and to apply ETV after 2 years of age ${ }^{(19)}$. But in the studies published later, in patients who did not have a VPS operation before, It has been demonstrated that ETV is statistically more successful ${ }^{(16)}$. Today, the trend is towards testing ETV in all appropriate cases, regardless of age, in order to offer all possible patients the luxury of living a life independent of shunt, even if the success rate is low $(3,8)$. Radiological examinations should be examined in detail before ETV is performed in a patient younger than two years old. In coronal sections, foramen Monro level, the width of the third ventricle should be at least $7 \mathrm{~mm}$; otherwise, the endoscope may cause hypothalamic damage ${ }^{(7}$, 13). In mid-saggital sections, basilar bifurcation and tuber cinerium anatomy are checked. Also, attention should be paid to the base of the third ventricle in mid-saggital sections; The suitability of the third ventricular base for ETV is checked (7).

There is no persistent complication or mortality rate due to ETV in our study. In the literature, $1 \%$ mortality, $1.6 \%$ permanent morbidity and $7.8 \%$ transient morbidity have been reported due to ETV ${ }^{(17)}$. Complications usually occur during the base perforation. Therefore, Tuber Cinerium should be perforated exactly midline between mamillary bodies and infundibular recess. Afterwards, it should be checked whether there is a Lilequist membrane under it. We believe that the complications will decrease with clinical experience. 


\section{CONCLUSION}

As a result, ETV is not a costly technique. It is not a difficult procedure to apply in experienced hands. Various success rates in younger children have been reported in many studies. If ETV procedure can provide shunt free life for patients it should be considered as first option.

Çıkar çatışması: Çalışmamızda herhangi bir çıkar çatışması bulunmamaktadır.

Finansal destek: Çalışmamızda finansal destek alınmamıştır.

Conflict of interest: There is no conflict of interest in our study.

Funding: No financial support was received in our study.

\section{REFERENCES}

1. Ammirati M, Raimondi A: Cerebrospinal fluid shunt infections in children: a study of the relationship between the etiology of the hydrocephalus, age at the time of shunt placement, and infection. Childs Nerv Syst 3:1069, 1987. https://doi.org/10.1007/BF00271135

2. Baskin JJ, Manwaring KH: Endoscopic third ventriculostomy for obstructive hydrocephalus. In: Rengachary SS, Wilkins RH (eds). Neurosurgical Operative Atlas. Illinois, AANS, Vol 5:241-246, 1996.

3. Buxton N, Macarthur D, Malucci C, Punt J, Vloeberghs $\mathrm{M}$ : Neuroendoscopic third ventriculostomy in patients less than one year old. Pediatr Neurosurg 29(2):73-76, 1998. https://doi.org/10.1159/000028693

4. Buxton N, Macarthur D, Robertson I, Punt J: Neuroendoscopic third ventriculostomy for failed shunts. Surg Neurol 60: 201- 203, 2003. https://doi.org/10.1016/ S0090-3019(03)00317-3

5. Cinalli G, Sainte-Rose C, Chumas P, Zerah M, Brunelle $\mathrm{F}$, Lot $\mathrm{G}$, et al. Failure of third ventriculostomy in the treatment of aqueductal stenosis in children.J Neurosurg 1999; 90: 448-54. https://doi.org/10.3171/ jns.1999.90.3.0448

6. Foroutan M, Mafee MF, Dujovny M: Third ventriculostomy, phase-contrast cine-MRI and endoscopic techniques. Neurol Res 20:443-448, 1998. https://doi.org/10.1080/01616412.1998.11740546
7. Hoffman HJ, Harwood-Nash D, Gilday DL: Percutaneous third ventriculostomy in the management of noncommunicating hydrocephalus. Neurosurgery 7:313-321, 1980. https://doi.org/10.1227/00006123198010000-00002

8. Hopf NJ, Grunert P, Fries G, Resch KD, Perneczky A. Endoscopic third ventriculostomy outcome analysis of 100 consecutive procedures. Neurosurgery 1999;44: 795-804. https://doi.org/10.1097/00006123-19990400000062

9. Jones RF, Kwork BC, Stening WA, et al: The current status of endoscopic third ventriculostomy in the management of non- communicating hydrocephalus. Minimally Invasive Neurosurg 37:28-36, 1994. https:// doi.org/10.1055/s-2008-1053445

10.Kelly PJ: Stereotactic third ventriculostomy in patients with nontumoral adolescent/adult onset aqueductal stenosis and symptomatic hydrocephalus. J Neurosurg 75:865-873, 1991. https://doi.org/10.3171/ jns.1991.75.6.0865

11.Kim SK, Wang KC, Cho BK: Surgical outcome of pediatric hydrocephalus treated by endoscopic III. ventriculostomy: prognostic factors and interpretation of postoperative neuroimaging. Child's Nerv Syst 16:161169, 2000. https://doi.org/10.1007/s003810050485

12.Rekate LH. Treatment of hydrocephalus. Principles and Practice of Pediatric Neurosurgery. In: Albright L, Pollack I, Adelson D. 1999;3,47-74.

13.Roth PA, Cohen RA: Management of hydrocephalus in infants and children. In: Tindall GT, Cooper PR, Barrow DL (eds). The Practice of Neurosurgery. Baltimore, Williams \& Wilkins, 2707- 2728, 1996.

14.Sainte-Rose C, Chumas P: Endoscopic third ventriculostomy. Techniques in Neurosurgery 1(3):176184, 1996.

15.Scarrow AM, Cohen AR: Neuroendoscopy. In: Albright AL, Pollack IF, Adelson PD (eds). Principles and Practice of Pediatric Neurosurgery. New York, Thieme, 91-106, 1999.

16.Scarrow AM, Levy EI, Pascucci L, et al: Outcome analysis of endoscopic III. ventriculostomy. Child's Nerv Syst 16:442-445, 2000. https://doi.org/10.1007/ s003810000307

17.Schroeder HWS, NiendorfWR, Gaab MR. Complications of endoscopic third ventriculostomy. J Neurosurg 2002; 96: 1032-40. https://doi.org/10.3171/jns.2002.96.6.1032

18.Siomin V, Weiner H, Wisoff J, et al. Repeat endoscopic third ventriculostomy: Is it worth trying? Child Nerv Syst 2001; 17: 551-5. https://doi.org/10.1007/s003810100475

19.Teo C, Jones R: Management of hydrocephalus by endoscopic third ventriculostomy in patients with myelomeningocele. Pediatr Neurosurg 25:57-63, 1996. https://doi.org/10.1159/000121098 